\title{
Reconstruction of the paleo-coastline of Santorini island (Greece), after the 1613 BC volcanic eruption: A GIS-based quantitative methodology
}

\author{
Dimitrios Oikonomidis*, Konstantinos Albanakis, Spyridon Pavlides \\ and MichaEL FytiKAS \\ Aristotle University of Thessaloniki, School of Geology, 54124, Thessaloniki, Greece. \\ *Corresponding author.e-mail: oikonomi@geo.auth.gr
}

\begin{abstract}
A catastrophic volcanic explosion took place in Thera/Santorini island around 1613 BC, known as the 'Minoan' eruption. Many papers have dealt with the shape of the shoreline of the island before the eruption, but none with the shape of the shoreline exactly after it, assuming that it would be the same with the contemporary one. However, this is not correct due to the wave erosion. In this paper, a new DEM was constructed, covering both land and submarine morphology, then topographic sections were drawn around the island. Using these sections, the 'missing parts' (sea-wave erosion) were calculated, the shoreline was reconstructed as it was one day after the eruption and finally the erosion rate was calculated.
\end{abstract}

\section{Introduction}

The study area is Thera/Santorini island complex, which is located in the southern Aegean Sea, Greece (figure 1a). It consists of the main island of Thera covering an area of $75.92 \mathrm{~km}^{2}$, Therasia $\left(9.19 \mathrm{~km}^{2}\right)$, Nea Kammeni where the volcano is located $\left(3.33 \mathrm{~km}^{2}\right)$, Palea Kammeni $\left(0.51 \mathrm{~km}^{2}\right)$ and Aspronisi $\left(0.12 \mathrm{~km}^{2}\right)$ (figure $\left.1 \mathrm{~b}\right)$. Geologically speaking, the volcanic products of the islands consist mainly of pumice/Minoan tuff (Thera and Therasia), lavas (mainly on Palea and Nea Kammeni) dating as old as $600 \mathrm{ka}$ to present day. The pre-volcanic basement is revealed in some parts of Thera (Mt. Profitis Ilias and Athinios), consisting of limestones and marbles, dating from Palaeocene-Eocene back to Triassic (Druitt and Davies 1999).

When the island of Thera erupted around 1613 BC (Friedrich and Heinemeier 2009), it produced one of the largest volcanic explosions in the Earth's history, changing dramatically the life of the people of the Bronze age in the eastern Mediterranean Basin. It also changed the morphology of the island itself, creating the famous caldera. This fact triggered the scientists' interest and many efforts have been made in order to reconstruct the morphology of the area as it was before the eruption (Heiken and McCoy 1984; Friedrich et al. 1988; Aston and Hardy 1990; Druitt and Francaviglia 1990; Heiken et al. 1990; Druitt and Francaviglia 1992; Druitt et al. 1999; Friedrich et al. 2000; Friedrich 2001).

However, the external shape of the island (outside of the caldera) did not remain unmodified after the eruption, as it is commonly believed. The island is surrounded by cliffy coastlines and sandy beaches. The case of cliff erosion and retreat of Santorini cliffy coastlines, due to wave action, has been underestimated in bibliography. According to Davidson-Arnott (2010), unlike sandy coasts where erosion may be reversed by deposition and

Keywords. Thera/Santorini; GIS; wave erosion; coastline. 


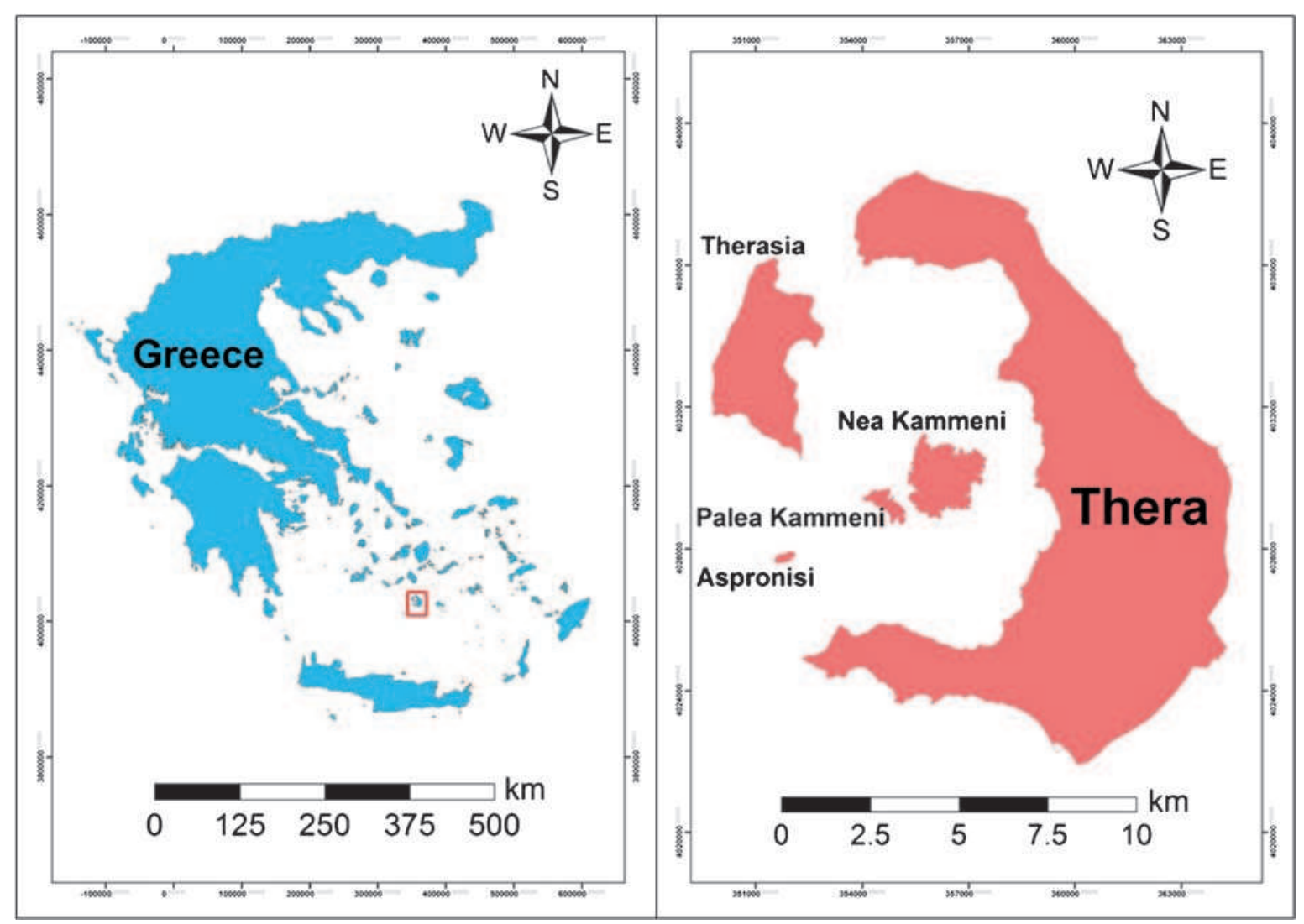

Figure 1. (a) Location of the study area (red rectangle) and (b) the Santorini island complex.

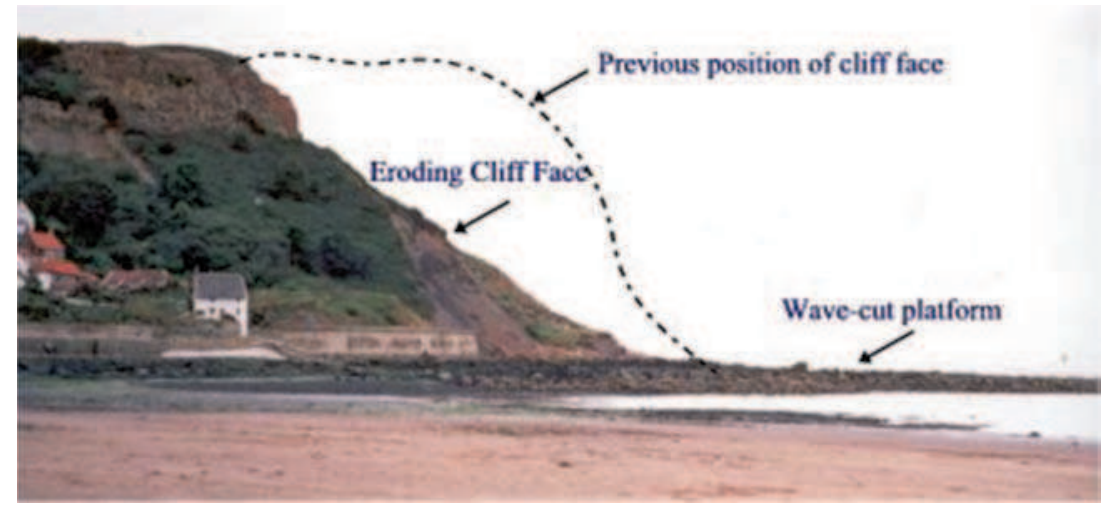

Figure 2. Long wave-length waves move sediments and erode bottom materials in substantial depths creating wave-cut platforms exposed during low tide as the above photo from the coast of Devon, England (URL1).

progradation, erosion of bedrock coasts destroys the bonding that provided strength and thus there is no reversal of the erosion process, cliffs remain stationary or they recede. On soft cliffy coasts (such as those developed on pumice-tuff/consolidated volcanic ash in the case of Santorini), wave action is able to erode the toe of the cliff relatively faster and to remove the eroded debris. Recession of the cliffs can be on the order of decimetres to metres per year
(Kirk 1977; Hequette and Barnes 1990; Jibson et al. 1994; Amin and Davidson-Arnott 1997; Sallenger et al. 2002; Gulyaev and Buckeridge 2004; Walkden and Hall 2005; Alvarez-Marron et al. 2008), and thus the cliff form is controlled by modern coastal processes and is not an inherited feature. Other natural causes of coastal erosion do not contribute significantly in the area. The most common of them are explained below: 


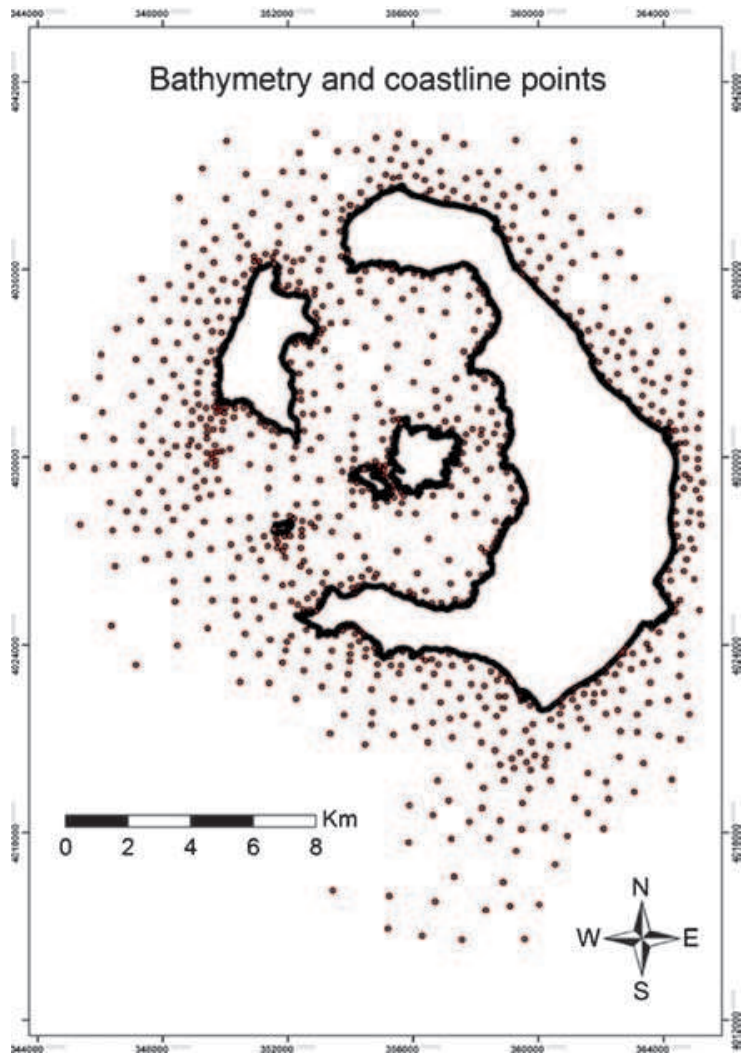

Figure 3. Distribution of water depths' points.
- Natural variation: The natural variation in the supply of sand to a coastline from a river can contribute to erosion. Droughts in large river basins can result in long periods with decreasing supplies of sand to the shoreline, leading to shore erosion. In our study area, the drainage network of the island is sparse, rare and periodical.

- Breaching and overwash: The loss of sand inland is due to breaching and overwash of a barrier island and wind transport. This kind of sand loss takes place along the exposed coasts of barrier islands which is certainly not the case in Santorini island complex.

- Protruding areas: The loss of material from a protruding area to one or two sides is a natural cause of coastal erosion. This typically happens at till/sandstone headlands and at the tip of deltas, which do not receive sufficient material from the river due to natural shifting of the river alignment. In the case of our study area, there are no river deltas at all.

Because of their relatively high rates of recession, these coasts offer an opportunity to study the controls on cliff erosion and profile evolution, and to extrapolate the results of these studies to hard-rock coasts. Studies of soft-rock coasts are also timely

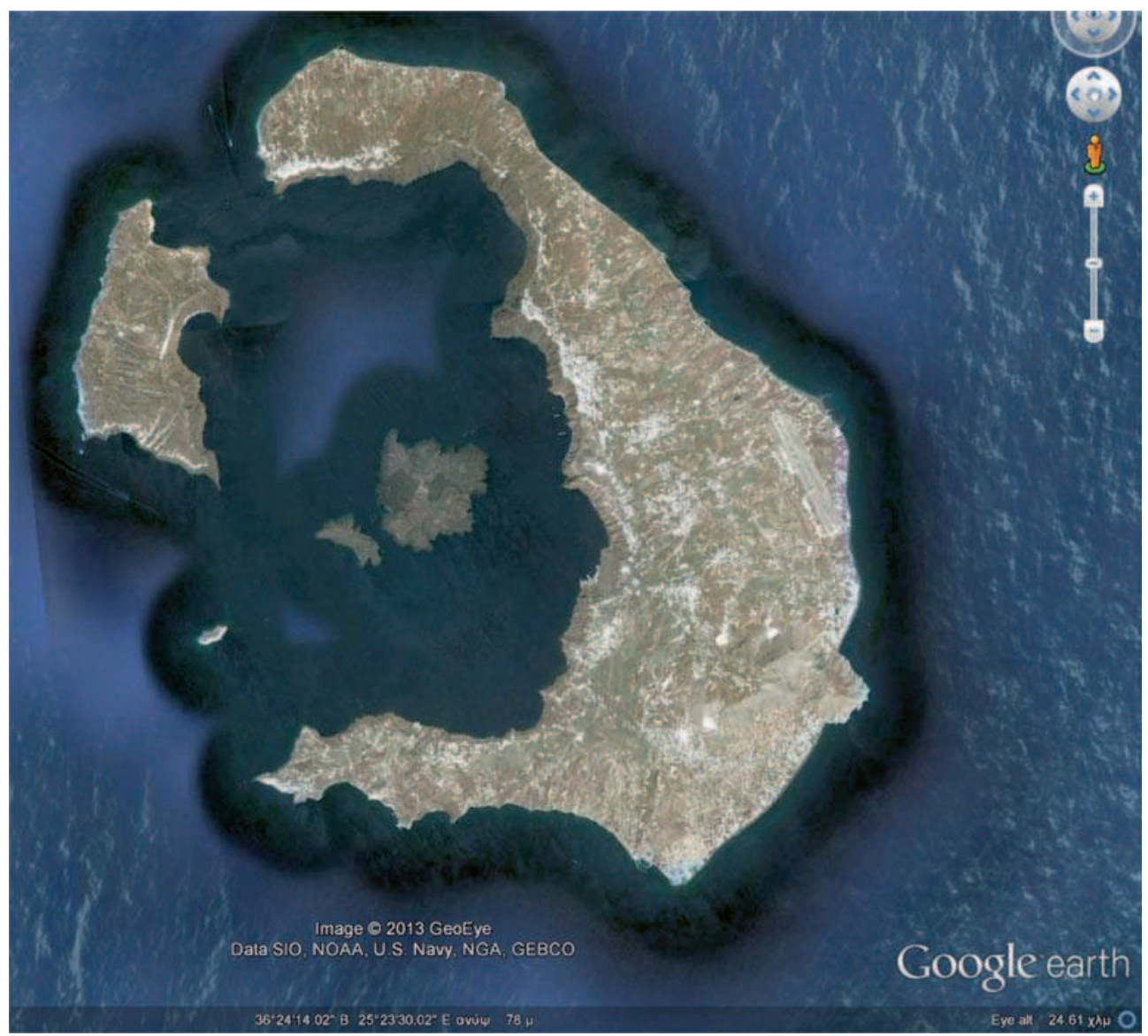

Figure 4. Google Earth satellite image of the Santorini island complex (URL2). 


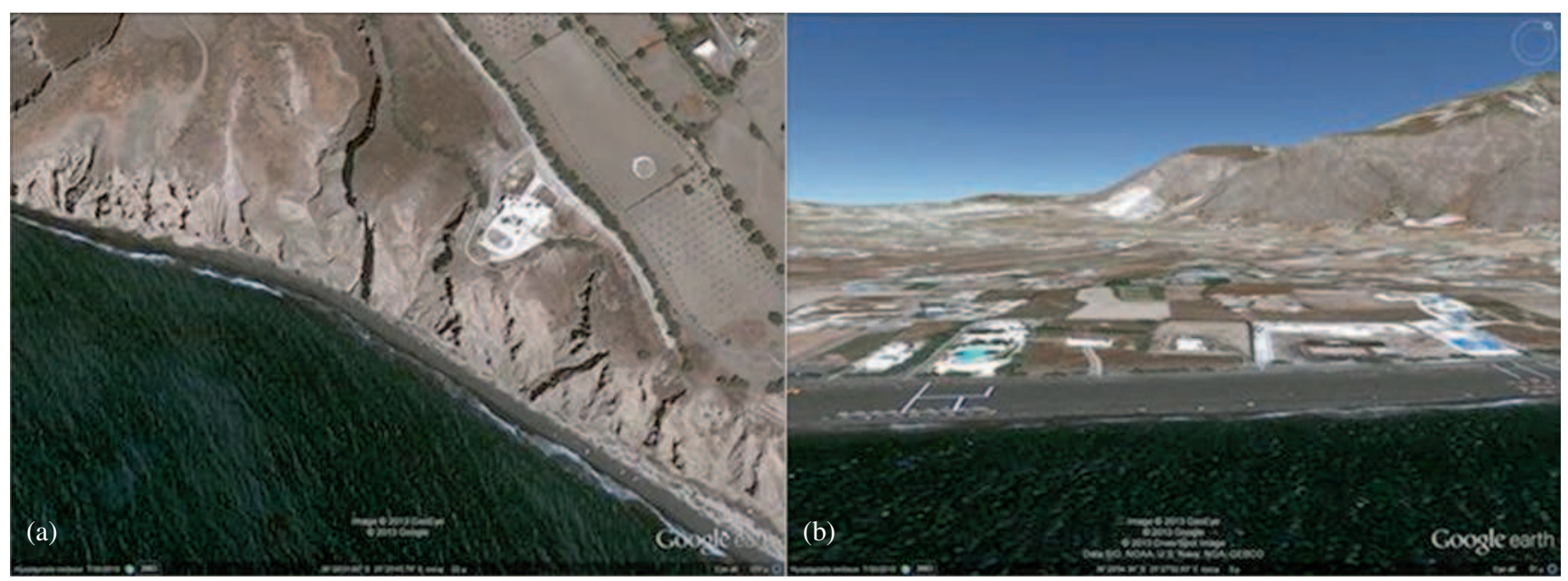

Figure 5. (a) A cliffed coastline. Intense erosional phenomena taking place. Location: Vlyhada area (south of the island). Source: Google Earth (URL2). (b) A typical coastline having equilibrium with sea-wave action. No erosion taking place. Location: Perissa beach (SE of the island). In the background (right), part of Mt. Profitis Ilias. Source: Google Earth (URL2).

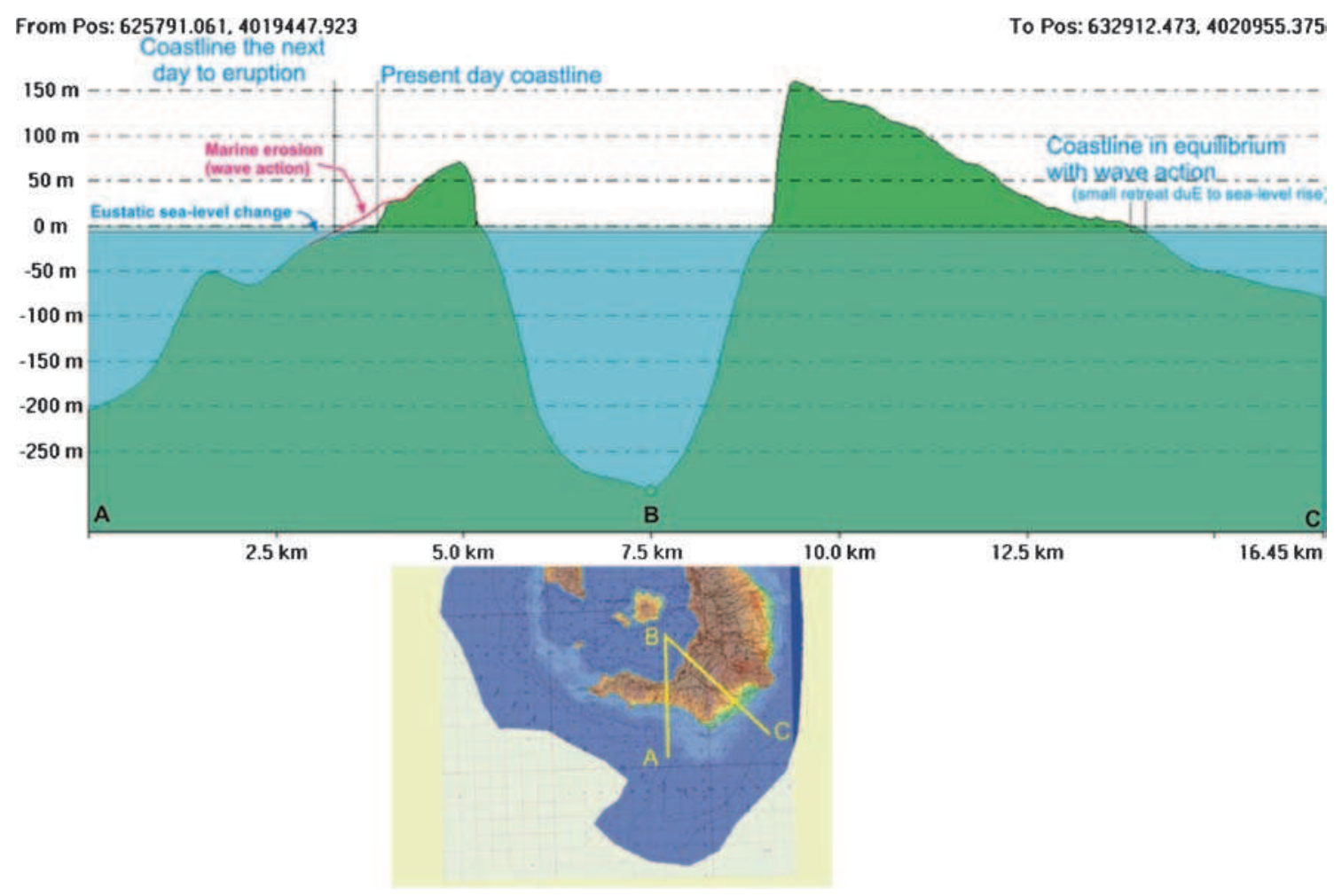

Figure 6. The two different types of coastlines in Thera.

because the high recession rates may result in threats to houses and infrastructure located on the cliff top and lead to call for intervention in the form of shore protection. The rate of the horizontal retreat of the cliff face can be as high as $100 \mathrm{~cm} / \mathrm{yr}$ in unconsolidated recent sediments (Davidson-Arnott 2010). As the cliff retreats, a gently-sloping rocky platform is left at the base; this is known as a wavecut platform which is exposed at low tide (figure 2).

The shallow coastal waters around the island reveal the presence of wave-cut platforms in several cases, indicating substantial coastal recession. Bibliographical references (Gelinas and Quigley 1973; Carter and Guy 1988; Bray and Hooke 1997; Sunamura 2004; Dong and Guzzetti 2005; Andriani and Walsh 2007; Collins and Sitar 2008), indicate medium-to-very high rates of coastal recession due to wave action. According to authors' knowledge of the area and information collected from the local residents, rates at the order of 20-100 $\mathrm{cm} / \mathrm{yr}$ are realistic in several locations in Santorini, especially in those with tuff (pumice) cliffs, since 
transportation of the eroded material by wave action is very strong.

\section{Data-methodology}

\subsection{Data}

The following data were used:

- Topographical map of $1 / 50,000$ scale. Sheet: Nisos Thira (Hellenic Army Geographical Service/HAGS).

- Google Earth v.6.2.2.6613 (URL2). Acquisition date of the satellite image: 30/07/2010.
- The Global Digital Elevation Model from ASTER satellite (ASTER/GDEM), horizontal spatial resolution $28 \mathrm{~m}$, free of charge (URL3).

- All the above data are georeferenced to the UTM/WGS84-35N projection. ArcGIS v.10.1 and Microsoft Excel software have been used.

\subsection{Land and bathymetry DEMs}

First of all, a DEM for land areas was needed. Unfortunately, 1 arcsec SRTM DEM is still not available for parts of the globe, including Greece. Therefore, we had to use the ASTER/GDEM for

Table 1. Numerical parameters of the polynomial equation for cliffs' cross-sections.

\begin{tabular}{|c|c|c|c|c|}
\hline $\begin{array}{l}\text { Profile } \\
\text { graph no. }\end{array}$ & Intercept & B1 & B2 & B3 \\
\hline 6 & 97.07623 & -0.07328 & $-4.17487 \mathrm{E}-5$ & $1.91632 \mathrm{E}-8$ \\
\hline 7 & 124.19632 & -0.35347 & 3.66122E-4 & $-1.35614 \mathrm{E}-7$ \\
\hline 8 & 114.50258 & -0.2274 & $2.29554 \mathrm{E}-4$ & $-9.36951 \mathrm{E}-8$ \\
\hline 12 & 108.91246 & -0.17328 & $1.14147 \mathrm{E}-4$ & $-3.58223 \mathrm{E}-8$ \\
\hline 13 & 100.19555 & -0.17894 & $1.29124 \mathrm{E}-4$ & $-4.82597 \mathrm{E}-8$ \\
\hline 16 & 173.66562 & -0.38329 & $2.89786 \mathrm{E}-4$ & $-7.61887 \mathrm{E}-8$ \\
\hline 17 & 62.74114 & -0.07357 & $3.40149 \mathrm{E}-5$ & $-9.52217 \mathrm{E}-9$ \\
\hline 18 & 165.29887 & -0.40336 & $3.16599 \mathrm{E}-4$ & $-8.27864 \mathrm{E}-8$ \\
\hline 19 & 108.53447 & -0.09221 & $3.24855 \mathrm{E}-5$ & $-4.9287 \mathrm{E}-9$ \\
\hline 20 & 115.58784 & -0.09125 & $3.33666 \mathrm{E}-5$ & $-5.56982 \mathrm{E}-9$ \\
\hline 21 & 83.98598 & -0.04741 & $1.60582 \mathrm{E}-5$ & $-4.00957 \mathrm{E}-9$ \\
\hline 22 & 68.81145 & -0.03252 & $5.37899 \mathrm{E}-6$ & $-1.48335 \mathrm{E}-9$ \\
\hline 23 & 49.46885 & 0.00114 & $-2.03559 \mathrm{E}-5$ & $3.72998 \mathrm{E}-9$ \\
\hline 24 & 102.03243 & -0.12996 & $5.12001 \mathrm{E}-5$ & $-7.27880 \mathrm{E}-9$ \\
\hline 25 & 54.35896 & -0.09770 & $5.05502 \mathrm{E}-5$ & $-9.14332 \mathrm{E}-9$ \\
\hline 35 & 61.65910 & -0.09461 & $5.89020 \mathrm{E}-5$ & $-1.48351 \mathrm{E}-8$ \\
\hline 36 & 78.88280 & -0.12659 & 8.63874E-5 & $-2.32180 \mathrm{E}-8$ \\
\hline 37 & -112.92208 & 0.37964 & $-2.98309 \mathrm{E}-4$ & $6.67884 \mathrm{E}-8$ \\
\hline 38 & 172.48463 & -0.25208 & $1.37807 \mathrm{E}-4$ & $-2.74777 \mathrm{E}-8$ \\
\hline 39 & 325.05666 & -0.50257 & $2.83219 \mathrm{E}-4$ & $-5.30444 \mathrm{E}-8$ \\
\hline 40 & 154.30886 & -0.21011 & $1.27553 \mathrm{E}-4$ & $-2.82480 \mathrm{E}-8$ \\
\hline 41 & 96.80554 & -0.13823 & $-3.49123 \mathrm{E}-4$ & $1.03008 \mathrm{E}-7$ \\
\hline 42 & -74.6547 & 0.32157 & $9.20004 \mathrm{E}-5$ & $-3.32147 \mathrm{E}-8$ \\
\hline 43 & 34.08896 & -0.09554 & $3.70287 \mathrm{E}-5$ & $1.63687 \mathrm{E}-8$ \\
\hline 44 & 26.12695 & -0.06447 & $-1.15032 \mathrm{E}-5$ & $4.27557 \mathrm{E}-8$ \\
\hline 45 & -11.46200 & 0.2549 & $-4.68881 \mathrm{E}-4$ & $2.5665 \mathrm{E}-7$ \\
\hline 46 & 60.34521 & -0.16201 & $1.6941 \mathrm{E}-4$ & $-7.7574 \mathrm{E}-8$ \\
\hline 47 & -16.60886 & 0.10630 & $-1.2054 \mathrm{E}-4$ & $3.31004 \mathrm{E}-8$ \\
\hline 48 & -273.44447 & 0.8541 & $-8.48255 \mathrm{E}-4$ & $2.71004 \mathrm{E}-7$ \\
\hline 49 & 19.22854 & -0.01411 & $1.09268 \mathrm{E}-5$ & $-5.52332 \mathrm{E}-9$ \\
\hline 50 & -31.6587 & 0.1774 & $-1.75118 \mathrm{E}-4$ & 4.48357E-8 \\
\hline 51 & 133.2228 & -0.33788 & $2.74225 \mathrm{E}-4$ & $-7.99701 \mathrm{E}-8$ \\
\hline 52 & 43.06788 & -0.04654 & $1.97842 \mathrm{E}-6$ & $1.7387 \mathrm{E}-9$ \\
\hline 53 & -271.35124 & 1.05864 & -0.00351 & $4.62867 \mathrm{E}-7$ \\
\hline 54 & -102.03804 & 0.4274 & $-5.05349 \mathrm{E}-4$ & $1.79753 \mathrm{E}-7$ \\
\hline 55 & -180.0666 & 0.54147 & $-4.83567 \mathrm{E}-4$ & $1.29394 \mathrm{E}-7$ \\
\hline 56 & -498.98114 & 1.58258 & -0.00744 & $4.98985 \mathrm{E}-7$ \\
\hline 57 & -18.1574 & 0.1112 & $-1.26358 \mathrm{E}-4$ & $3.70455 \mathrm{E}-8$ \\
\hline 58 & 442.46123 & -0.92555 & $6.42878 \mathrm{E}-4$ & $-1.51956 \mathrm{E}-7$ \\
\hline 59 & -38.31952 & 0.22477 & $-2.67222 \mathrm{E}-4$ & 8.55021E-8 \\
\hline
\end{tabular}


our purpose, since the spatial resolution of the previous versions of SRTM is too coarse $(90 \times 90 \mathrm{~m})$. Following the methodology of Ramakrishnan et al. (2013), the DEM was filled and then calibrated with information on $\mathrm{X}, \mathrm{Y}$ and $\mathrm{Z}$ values collected in the field, using measurements of recent expeditions on the island, from a Differential Global Positioning System (DGPS). In all, 43 ground control points (GCPs) were used in order to fit a secondorder polynomial equation and calibrate the DEM.

Then, the sea-water depths on the topographic map were digitized. The depths' information on the topographic map was provided by the Hellenic Navy (detailed point measurements, not iso-depth contours). These depths (point shapefile) were added to the 0 -value points of the coastline (figure 3 ), thus creating a bathymetry DEM, assigned a spatial resolution of $28 \mathrm{~m}$, same as that of the ASTER/ GDEM (of the land). Due to different vertical accuracies of the two datasets (ASTER/GDEM and bathymetry DEM), an error normalization was performed before a composite DEM was created, yielding a root mean square deviation (RMSD) of $1.51 \mathrm{~m}$ and a bias of 0.15 .

What was needed for our purpose, was a single DEM, including both land and sea areas. For this reason, initially, the present coastline of the islands was digitized as a polygon feature from Google Earth satellite image (figure 4), within Google Earth environment. The exported .kmz files were imported to ArcMap and converted to polygon and polyline shapefiles (.shp). The polyline shapefile of the islands was converted to points shapefile and all points were attributed 0 -value (coastline). Subsequently, the area of the islands was calculated (see 'introduction'). The polygon shapefile was used as a mask in order to extract the land part of ASTER/GDEM. The polyline shapefile was used for zero contour creation, since the ASTER/GDEM, has many errors around sea-level.

\subsection{Topographic cross-sections}

In Thera, presence of two types of coasts can be detected: (1) cliffs, which have suffered sea-wave erosion (figures 5a and 6 ) and (2) beaches/coastlines being in equilibrium with wave action (figures $5 \mathrm{~b}$ and 6 ). In order to reconstruct the coastline of the island as it was one day after the volcanic eruption of $1613 \mathrm{BC}$, that is before the sea-waves started the erosion process, we must fill the missing (eroded) part in the topographic cross-section (figure 6/red line). For this reason, the newlycreated DEM, covering both land and sea areas was used.

The new methodology developed is as follows: Numerous linear shapefiles were created within ArcCatalog, possessing the same projection system as the DEM, that is UTM/WGS84/35N. These empty linear shapefiles were imported into ArcMap and were used in order to digitize 59 topographic cross-sections, covering both land and sea around the island. The profile graph of each cross-section was exported as Excel file (1.xls). The linear shapefile (1.shp) was converted to point shapefile (1points.shp) and two columns were added in its attribute table, having the information of XY coordinates. The 1points.shp was converted to excel too (1_points.xls).

Data of the two aforementioned excel files were merged to a single one (1final.xls), and a profile graph was created. In this graph, the missing/ eroded part was filled-in with imported values, using a third-order polynomial equation (1), taking into consideration that the missing part of the graph would resemble a slightly curved line, being directed to this reconstruction by the shape of the graph and the relative distances of the modern relief. Thus, the profile graph of the day after the eruption was created. This excel file was imported back to ArcMap and converted to point shapefile (1final.shp).

$$
y=\text { Intercept }+\mathrm{B} 1 * x+\mathrm{B} 2 * x^{2}+\mathrm{B} 3 * x^{3}
$$

where $x$ corresponds to the horizontal distance from the beginning of the cross-section (depicted as ' $\mathrm{d}$ ' in the diagrams of figure 9) and $y$ corresponds to the heights/depths (depicted as $\mathrm{z}$ in the same diagrams); $x$ and $y$ values are in meters. Table 1

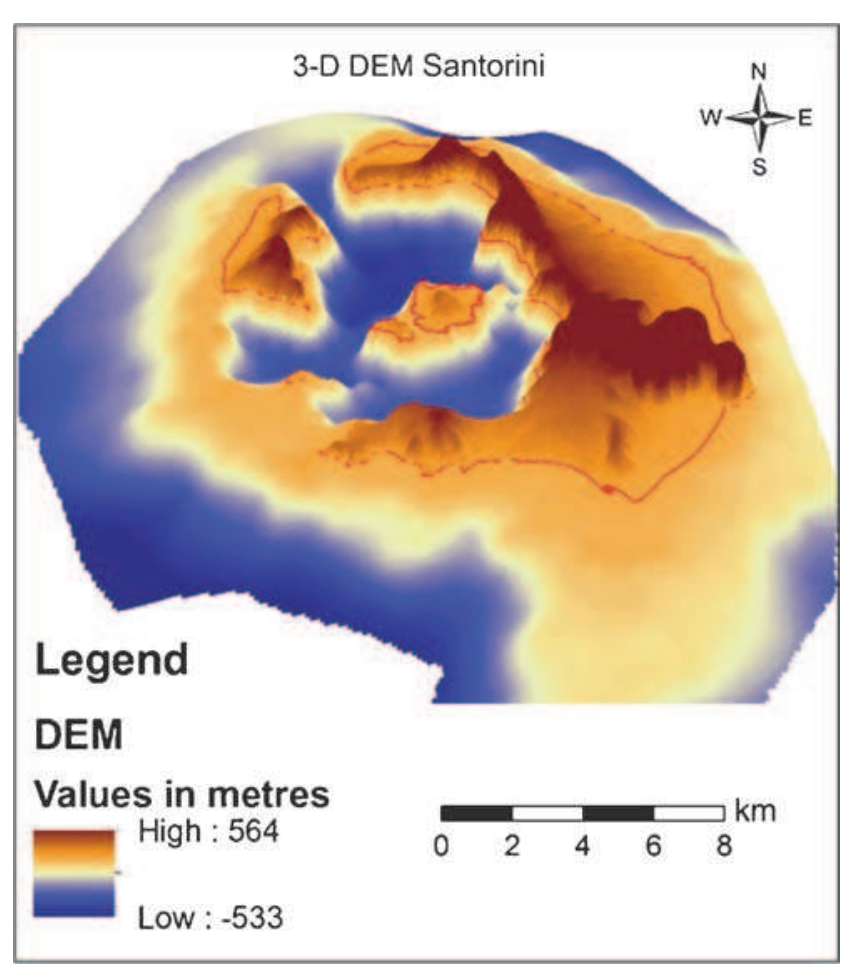

Figure 7. Final DEM created, covering both land and sea (3-D view). Present coastline with red line. 
contains the numerical parameters of the equation (1) for each cross-section/profile graph.

\section{Synthesis and results}

Unlike coasts dominated by sedimentary deposits, where the beach and near-shore can be altered continuously but maintain a long-term equilibrium form and location, the dominant focus in cliffed coasts is on erosional processes (Davidson-Arnott 2010). Thus, while on a sedimentary coast, erosion can be balanced by subsequent accretion, on a cliffed coast, erosion results in the breakdown of the constituent material forming the cliff and it is a process that cannot be reversed.
Underwater morphology, wave energy calculations, coastal geomorphology and geological composition of the coast, were taken into consideration in reconstructing the paleo-coast from modern morphological profiles. In locations where a cliff and a wave-cut platform were detected, a new profile was created representing the morphology just after the volcanic eruption of 1613 BC. A new $0 \mathrm{~m}$-contour was created by this procedure about $3 \mathrm{~m}$ below present sea-level to incorporate eustatic change.

For the purpose of our study, a single DEM was created, covering both land and sea, by combining the ASTER/GDEM (land) and the bathymetry DEM. A 3D-view of the islands and the sea-floor can be seen in figure 7 .

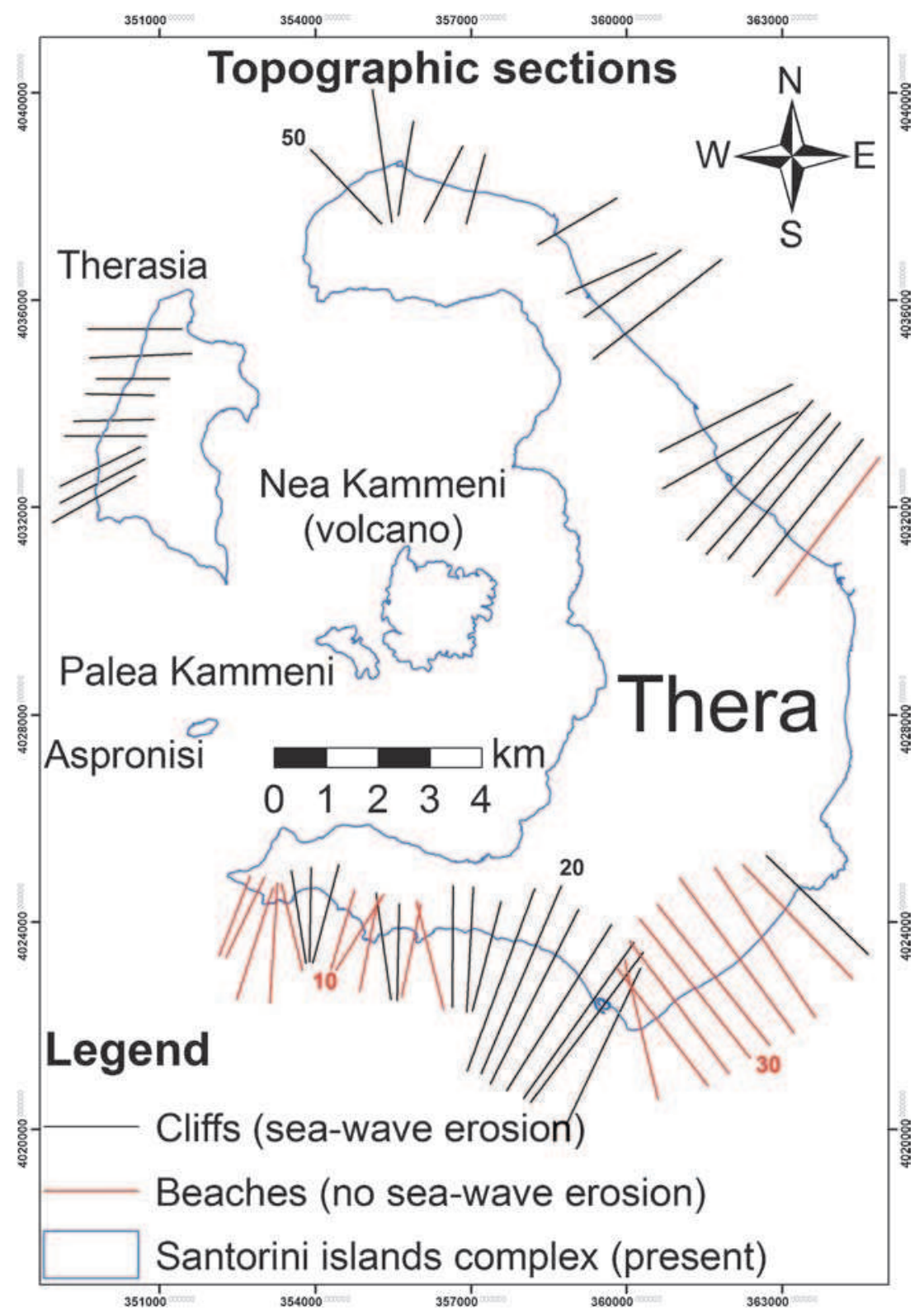

Figure 8. Location of topographic cross-sections. 

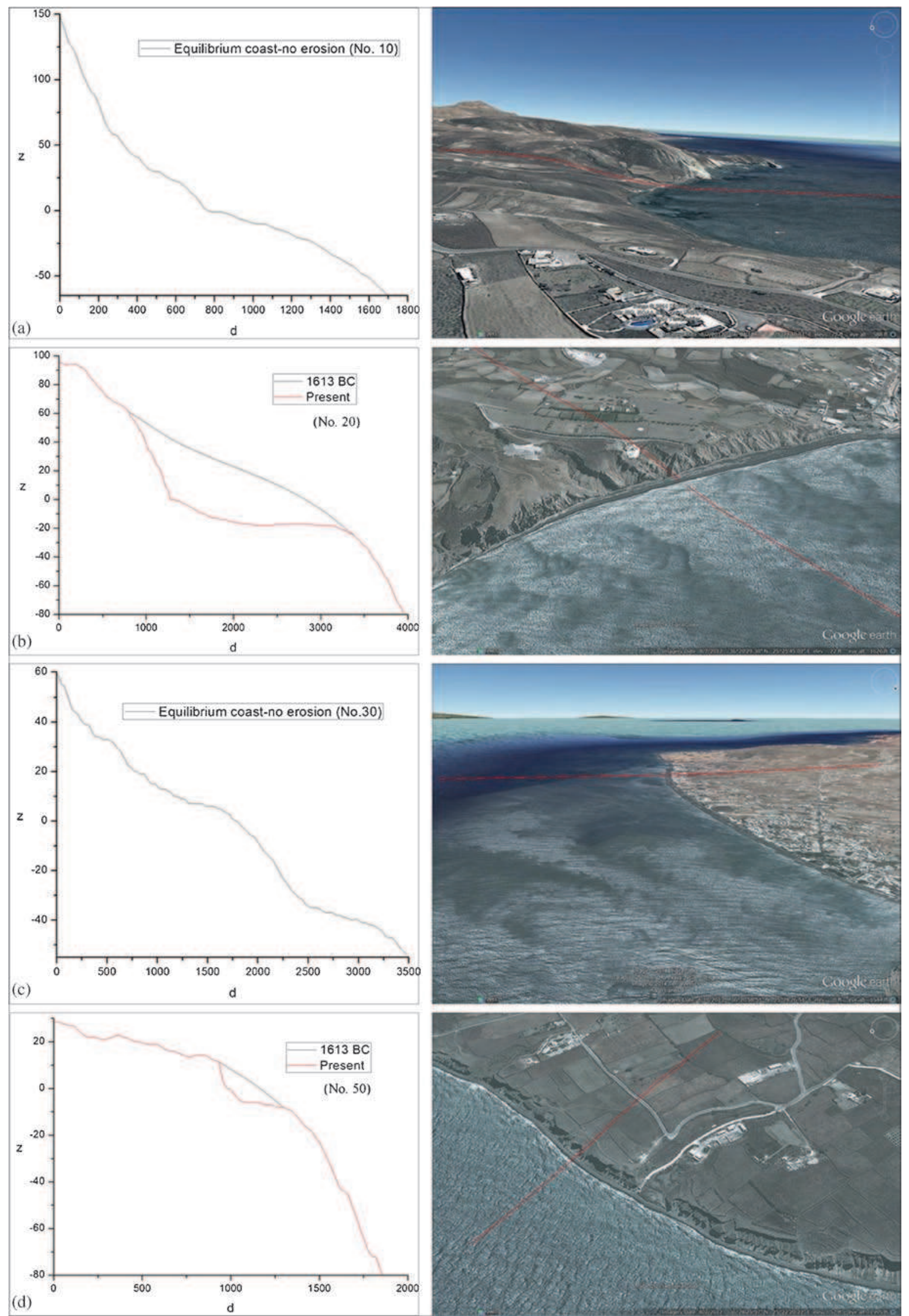

Figure 9. Topographic cross-sections of cliffed coasts ( $\mathbf{b}$ and $\mathbf{d}$ ) and equilibrium coasts - no erosion (a and $\mathbf{c}$ ). On cliffedcoasts, the present profile is depicted with red line and the eroded-reconstructed part is depicted with blue line. On equilibrium coasts - no erosion, blue line represents present coastline. 


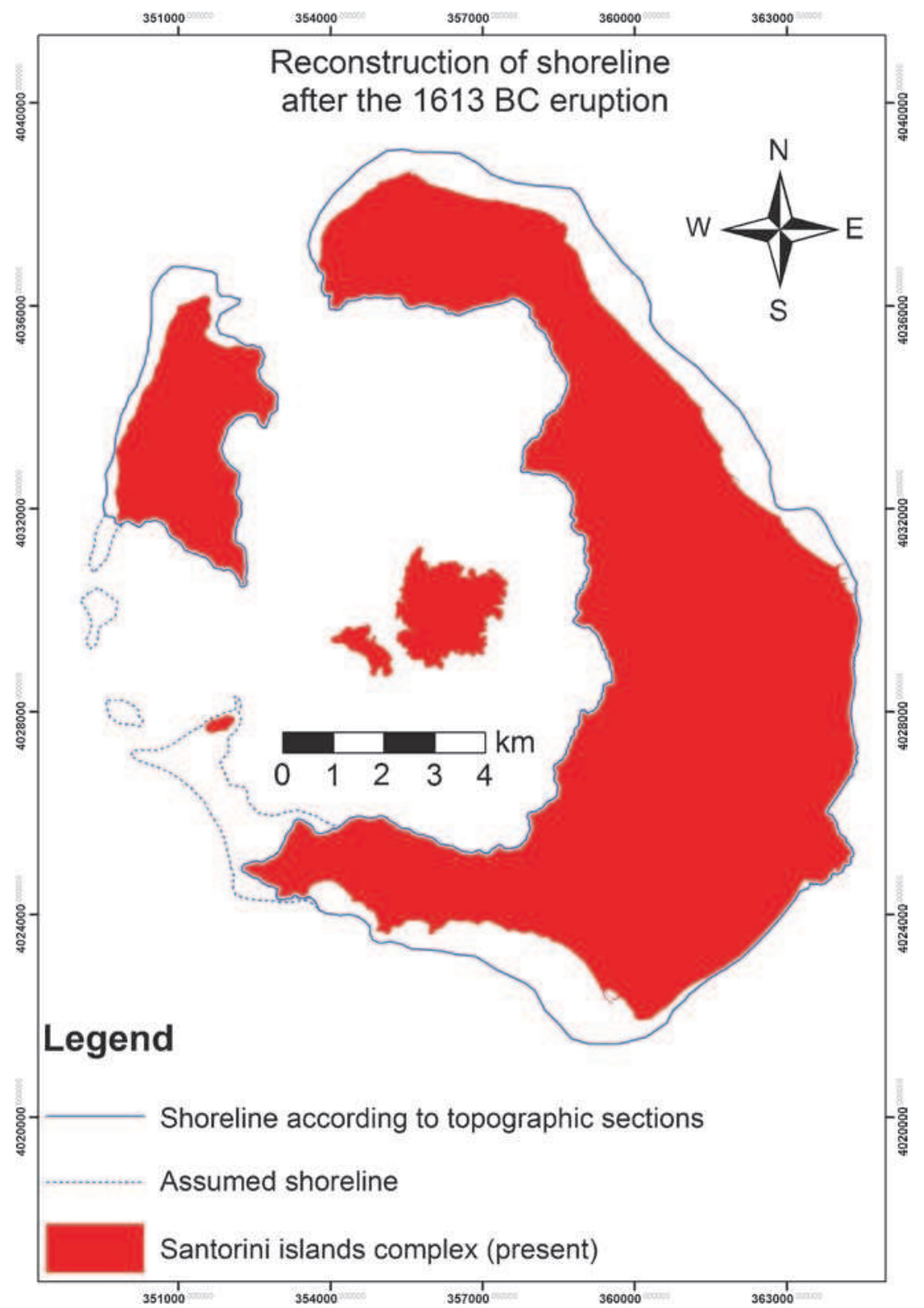

Figure 10. The re-constructed coastline of Thera/Santorini island complex. The dashed line was not produced from the methodology, but it was added based on the authors' knowledge of the area.

Fifty nine cross-sections were created based on the above DEM, covering both land and sea (figure $8)$. Out of which 40 revealed coastlines with seawave erosion, while 19 showed coastlines with equilibrium and wave action (figures 8 and 9).

Having the final point shapefiles added to ArcMap, all the 0 -value points were selected and the coastline of one day after the eruption of 1613 BC, was delineated, before the sea-wave erosion started acting. This new shoreline is represented graphically in the following figures, postulating the morphology of Santorini, a day after the Minoan eruption (figure 10).

The most intense sea-wave erosion (old coastline minus modern coastline) was measured to be $1181 \mathrm{~m}$ on the south of the island, thus yielding a horizontal wave erosion rate of $32.81 \mathrm{~cm} / \mathrm{yr}$ (maximum). In the islands of Thera and Therasia, 15.77 and $2.67 \mathrm{~km}^{2}$ of coastal land were eroded respectively. Since the big volcanic eruption of $1613 \mathrm{BC}$, a total of $18.44 \mathrm{~km}^{2}$ (Thera + Therasia) was removed, giving a mean erosion rate of 0.005 $\mathrm{km}^{2} / \mathrm{yr}$.

\section{Conclusions}

The devastating volcanic eruption of $1613 \pm 13$ $\mathrm{BC}$, according to the latest dating of Friedrich and Heinemeier (2009), changed dramatically the morphology of the Santorini island, but the topography did not remain unchanged since then, 
not only inside the caldera (creation of Palea and NeaKammeni islands), but also out of it, peripherally of the island, due to sea-wave erosion of soft tuff/pumice (produced by the volcanic eruption), a factor not taken into consideration as seriously as it should be.

The methodology developed by the research team provides quantitative results on the sea-wave erosion in Thera/Santorini island complex, outside of the caldera, for the first time. Given the fact that the intensity of the process remained the same throughout the lapsed period due to stable meteorological and eustatic conditions (Rackam 1990; Tyrlis and Lelieveld 2013), the results have not only scientific/historical interest but can also have a practical application, that is to be used in the prediction of sea-wave erosion course in various parts of the island, providing the local and government authorities with valuable information about the endangered areas, since the island is visited by large number of tourists every year. Compared with other natural hazards, such as earthquakes, volcanic eruptions and landslides, shoreline erosion appears to be a more continuous and predictable process that causes relatively modest damage to limited areas. In reality, the shoreline is one of Earth's most dynamic places that changes rapidly in response to natural forces. Storms, for example, are capable of eroding beaches and cliffs at rates that far exceed the long-term average. Such bursts of accelerated erosion not only have a significant impact on the natural evolution of a coast, but can also have a profound impact on people who reside in the coastal zone. Erosion along the coast causes significant property damage. Huge sums are spent annually not only to repair damage but also in an attempt to prevent or control erosion. Already a problem at many sites, shoreline erosion is certain to become increasingly serious as extensive coastal development continues.

However, the loss of volume of a significant part of the island in a relatively short period of time, did not cause any observed isostatic rebound related effects (Papageorgiou et al. 1990; Pavlopoulos et al. 2011), probably due to the fact that the removed rock is pumice, which is a very light material, possessing a specific gravity of $0.641 \mathrm{~g} / \mathrm{cm}^{3}$.

This new, low-cost, GIS-based methodology does not aim in describing the general framework or the theoretical approach of the coastal erosion system. The effectiveness and the simplicity of this new quantitative methodology of reconstructing the paleo-coast is the most important matter, since it can be applied by anyone in all sea-side areas suffering from wave erosion, especially on cliffed coasts, provided that a DEM and some bathymetry data are acquired.

\section{References}

Alvarez-Marron J, Hetzel R, Niedermann S, Menendez R and Marquinez J 2008 Origin, structure and exposure history of a wave-cut platform more than $1 \mathrm{Ma}$ in age at the coast of northern Spain: A multiple cosmogenic nuclide approach; Geomorphology 93 316-334.

Amin S M N and Davidson-Arnott R G D 1997 A statistical analysis of the controls on shoreline erosion rates, Lake Ontario; J. Coast. Res. 13 1093-1101.

Andriani G F and Walsh N 2007 Rocky coast geomorphology and erosional processes: A case study along the Murgia coastline south of Bari, Apulia-SE Italy; Geomorphology $87224-238$.

Aston M A and Hardy P G 1990 The pre-Minoan landscape of Thera: A preliminary statement; In: Thera and the Aegean World III (ed.) Hardy D A (London: The Thera Foundation) 2 348-361.

Bray M J and Hooke J M 1997 Prediction of soft-cliff retreat with accelerating sea-level rise; J. Coast. Res. 13 453467.

Carter C H and Guy D E Jr 1988 Coastal erosion: Processes, timing and magnitudes at the bluff toe; Marine Geol. 84 $1-17$.

Collins B D and Sitar N 2008 Processes of coastal bluff erosion in weakly lithified sands, Pacifica, California, USA; Geomorphology 97 483-501.

Davidson-Arnott R 2010 An introduction to coastal processes and geomorphology; Cambridge University Press, Cambridge, UK, 442p.

Dong P and Guzzetti F 2005 Frequency-size statistics of soft-cliff erosion; J. Waterway, Port, Coastal and Ocean Engg. 131 37-42.

Druitt T H and Francaviglia V 1990 An ancient caldera cliff line at Phira, and its significance for the topography and geology of pre-Minoan Santorini; In: Thera and the Aegean World III (ed.) Hardy D A (London: The Thera Foundation) 2 362-369.

Druitt T H and Francaviglia V 1992 Caldera formation on Santorini and the physiogeography of the islands in the Late Bronze Age; Bull. Volcanol. 54 484-493.

Druitt T H and Davies M 1999 Geological map of the Santorini islands. Aegean Sea, Greece (1:20.000); Appendix to: Santorini Volcano; In: Geological Society Memoir, No. 19, Geological Society, London, UK.

Druitt T H, Edwards L, Mellors R M, Pyle D M, Sparks R S J, Lanphere M, Davies M and Barriero B 1999 Santorini Volcano; In: Geological Society Memoir, No. 19, Geological Society, London (including geological map).

Friedrich L W and Heinemeier J 2009 The Minoan eruption of Santorini radiocarbon dated to $1613 \pm 13 \mathrm{BC}$ - geological and stratigraphic consideration; In: "Time's Up" Dating the Minoan eruption of Santorini (ed.) Warburton D A (Greece: The Danish Institute of Athens) 10 56-63.

Friedrich W, Eriksen U, Tauber H, Heinemeier J, Rud N, Thomsen M S and Buchardt B 1988 Existence of a waterfilled caldera prior to the Minoan eruption of Santorini, Greece; Naturwissenschaften 75 567-569.

Friedrich W L, Seidenkrantz M S and Ole B N 2000 Santorini (Greece) before the Minoan eruption: A reconstruction of the ring-island, natural resources and clay deposits from the Akrotiri excavation; In: The Archaeology of Geological Catastrophes (eds) McGuire W J, Griffiths D R, Hancock P L and Stewart I S, London, Geol. Soc. Spec. Publ. 171 71-80.

Friedrich W 2001 Fire in the Sea. The Santorini Volcano: Natural History and the Legend of Atlantis; Cambridge University Press. 
Gelinas P J and Quigley R M 1973 The influence of geology on erosion rates along the north shore of Lake Erie; In: Proceedings of the 16th Conference on Great Lakes Research, pp. 421-430.

Gulyaev S A and Buckeridge J S 2004 Terrestrial methods for monitoring cliff erosion in an urban environment; J. Coast. Res. 20 871-878.

Heiken G and McCoy F 1984 Caldera development during the Minoan eruption, Thira, Cyclades, Greece; J. Geophys. Res. 89 8441-8462.

Heiken G, McCoy F and Sheridan M 1990 Palaeotopographic and palaeogeologic construction of Minoan Thera; In: Thera and the Aegean World III (ed.) Hardy D A (London: The Thera Foundation) 2 370-376.

Hequette A and Barnes P W 1990 Coastal retreat and shoreface profile variations in the Canadian Beaufort Sea; Marine Geol. 91 113-132.

Jibson R W, Odum J K and Staude J M 1994 Rates and processes of bluff recession along the Lake Michigan Shoreline in Illinois; J. Great Lakes Res. 20 135152.

Kirk R M 1977 Rates and forms of erosion on intertidal platforms at Kaikoura Peninsula, South Island, New Zealand; New Zealand J. Geol. Geophys. 20 571-613.

Papageorgiou S, Stiros S and Sigals C 1990 New evidence of late Holocene sea-level changes in the Aegean and Santorini: Tectonic, eustatic and volcanological effects; In: Thera and the Aegean World III (ed.) Hardy D A (London: The Thera Foundation) 2 416-420.
Pavlopoulos K, Kapsimalis V, Theodorakopoulou K and Panagiotopoulos I 2011 Vertical displacement trends in the Aegean coastal zone (NE Mediterranean) during the Holocene assessed by geo-archaeological data; The Holocene 22 717-728.

Rackam O 1990 Observations on the historical ecology of Santorini; In: Thera and the Aegean World III (ed.) Hardy D A (London: The Thera Foundation) 2 384-391.

Ramakrishnan D, Singh N, Verma A K, Gulati A and Tiwari K C 2013 Soft computing and GIS for landslide susceptibility assessment in Tawaghat area, Kumaon Himalaya, India; Natural Hazards 65 315-330.

Sallenger A H Jr, Krabill W, Brock J, Swift R, Manizade S and Stockdon H 2002 Sea-cliff erosion as a function of beach changes and extreme wave runup during the 19971998 El Nino; Marine Geol. 187 279-297.

Sunamura T 2004 Cliffs, lithology versus erosion rates; In: Encyclopedia of Coastal Sciences (ed.) Schwartz M, Kluwer, Dordrecht, pp. 241-243.

Tyrlis E and Lelieveld J 2013 Climatology and dynamics of the summer Etesian winds over the eastern Mediterranean; J. Atmos. Sci. 70 3374-3396.

Walkden M J A and Hall J W 2005 A predictive mesoscale model of the erosion and profile development of soft rock shores; Coastal Engg. 52 535-563.

URL1. http://www.southwestcoastalgroup.org.uk/cc_how_ wavecut.html.

URL2. http://www.google.gr/intl/el/earth/index.html.

URL3. http://www.gdem.aster.ersdac.or.jp. 